\title{
Financial Accounting Standards for Micro, Small \& Medium Entities (SAK EMKM) Implementation and Factors That Affect It
}

\author{
Nur Diana *)
}

\begin{abstract}
The low understanding of accounting and financial accounting standards is a fundamental problem for Micro, Small \& Medium Enterprises (MSMEs) in Indonesia. This makes it difficult to prepare and manage financial statements. The presence of the Financial Accounting Standards for Non-Publicly-Accountable Entities (SAK-ETAP) on January 1, 2011, is expected to accommodate small and medium enterprises in making easy, transparent and accountable financial statements. But In fact, many MSMEs that have not been able to apply SAK ETAP properly because it is considered to be too complex and not by the financial reporting needs of MSMEs. On January 1, 2018, SAK EMKM was enacted as a standard that could help about 57.9 million MSME entrepreneurs in Indonesia in properly preparing their financial statements without having to get caught up in the complexity of it. SAK EMKM is a much simpler financial accounting standard than SAK ETAP. This study aims to provide empirical evidence on the perception of MSME business actors regarding the importance of financial bookkeeping and reporting for their business and the factors that affect the level of understanding of MSME's related to SAK EMKM. The sample of research was MSMEs business actors in Malang Raya with purposive sampling method with the total of 225 respondents. The results showed that company size, educational background, and level of education affect the MSME business entrepreneurs' perception of the importance of financial bookkeeping and reporting. While the level of understanding of MSME business entrepreneurs of SAK EMKM is affected by the level of information on SAK EMKM, educational background and education level of the MSME business actors.
\end{abstract}

Keywords: SAK EMKM; Educational Background; Level of Education; Business Size; MSME's Business Entrepreneurs Perceptions; Financial Statements

\section{INTRODUCTION}

\subsection{Research Background}

Financial management is one of the fundamental problems in the development of small and medium enterprises. Many small and medium-sized businesses think that financial management is easy and simple. In fact, financial management in SMEs requires good accounting skills by small and medium business entrepreneurs. Some weaknesses in the preparation of financial statements due to low understanding of accounting and financial accounting standards and the low education of SMEs in addition to the absence of regulations that require the preparation of financial statements. MSMEs objected to the same SAK with Large Enterprises in the preparation of financial statements. Benefits of the preparation of financial statements are much more perceived by Large Enterprises while SMEs have to spend a greater cost than to feel the benefits of the preparation of financial statements (Wahdini, 2006). This resulted in the constraints of MSMEs in obtaining access to capital provided by financial institutions due to the tight financial reporting requirements (Cahyati, Mulyanti, \& Setyawasih, 2011). The financial statements should be prepared by the applicable financial accounting standards in Indonesia for MSMEs seeking to obtain credit in a financial institution. Baas \& Schrooten (2006) stated that the banks as credit distributors of MSMEs need accounting information related to SMEs business to disburse the credit. However, most 
MSMEs do not bookkeep to report their business in accordance with the reporting format required by MSME credit channelers. If MSMEs do not make financial reports by standard accounting rules, credit distributors will find it difficult to assess the business performance of the MSMEs concerned. The SME Bookkeeping System tends to be simple and ignores the standard financial administration rules. Financial statements by financial accounting standards will assist in both quantitative and qualitative business development efforts. The financial statements are also used to determine the company's business development, financial position, capital structure and profit (revenue) of a company. Financial Accounting Standards for Non- Publicly-Accountable Entities (SAK-ETAP) was effective as of January 1, 2011. This standard was published with the aim of facilitating its users in applying accounting principles that are still not suitable by using common SAK. SAKETAP is expected to accommodate small and medium-sized enterprises in making easy, transparent and accountable financial statements, so there is no need to prepare financial statements using the applicable general GAAP (Damarjati, 2007). However, the implementation of this standard is still facing many obstacles such as SAK ETAP is too complex. Besides, there is no supervision from the parties concerned to MSMEs financial reports, especially from the government, related institutions, and regulators.

To bridge this issue on January 1, 2018, SAK EMKM has been effective to encourage and facilitate the needs of micro, small and medium enterprise (MSME) entrepreneurs. SAK EMKM is issued to assist MSME in Indonesia which currently amounts to 57 Million and contributes to Indonesia's economic growth up to 60\%. Most of these MSMEs are small business actors who have business prospects but do not have good access to funding sources, especially in banking. The MSME reporting framework is expected to assist the entity in transitioning from cash-based financial reporting to financial reporting on the accrual basis. Therefore, this is in line with Article 29 paragraph 1 of Act No. 1 of 2013 on Micro Finance Institutions that require Micro Finance Institutions to conduct and maintain records and/or financial bookkeeping in accordance with the applicable Financial Accounting Standards. Efforts have been made to socialize and improve the understanding of MSME business actors to SAK EMKM to facilitate them in preparing financial statements. There are several factors that affect the level of information and socialization received by MSME entrepreneurs, the size of the business, the establishment of the company, the background of MSME business actors, and the level education of MSME (Rudiantoro \& Veronica, 2011). Malang Raya is an area consisting of Malang City, Malang Regency, and Batu City as a city of commerce, industry, and tourism that has a lot of superior SME products like ceramics industry centers, furniture, food; tempe chips and fruit chips. Currently, Malang Raya has approximately 200 thousand SMEs and has employed 250 thousand workers. Based on this, Malang Raya is a potential area in SME development so it is very reasonable if the Office of Cooperatives and SMEs stated if the government will provide access to credit and bring together SMEs, cooperatives, and banks to overcome capital difficulties. This makes SMEs in Malang are in need of accounting information in making business decisions. This research responds to issues concerning the factors that affect the perception of SMEs entrepreneurs regarding the importance of financial reporting for their business and the factors that affect the level of understanding of SME business actors related to the implementation of the Micro, Small and Medium Enterprise Financial Accounting Standards.

\subsection{Research Problem}

Based on the above reasoning, the researcher needs to investigate empirical evidence about the level of understanding of MSMEs related to SAK EMKM by MSME business entrepreneur.

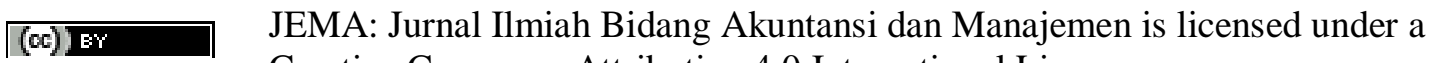
Creative Commons Attribution 4.0 International License 
JEMA: Jurnal Ilmiah Bidang Akuntansi dan Manajemen, Vol. 15 No. 2 (2018)

http://riset.unisma.ac.id/index.php/jema (e-ISSN : 2597-4071)

\subsection{Research Purpose}

The purpose of this study is to provide empirical evidence on perceptions about the level of understanding of MSMEs related to SAK EMKM by MSME business entrepreneur.

\section{THEORETICAL FRAMEWORK AND HYPOTHESES DEVELOPMENT}

\subsection{The Importance of SAK EMKM}

Tambunan (2012) states that the problems that are often faced by SMEs are about the limitations of working capital and investment, difficulties in marketing, distribution and procurement of raw materials and other inputs, limited access to information about market opportunities and others, the limitations of workers with high expertise and technological capabilities, high transportation and energy costs; communication limitations, high costs due to complex administrative and bureaucratic procedures, especially in the processing of business licenses, and uncertainty due to unclear or uncertain regulations and economic policies. From those various limitations faced by MSMEs, the biggest problem is about the limitations of capital. Some MSMEs do not obtain bank loans or other institutions because their business is not feasible to be funded, less able to meet the requirements in administration, or do not have assets that can be used as collateral. Therefore, to improve the quality of financial statements made by MSME entrepreneurs, the appropriate standards are required, then to overcome the Financial Accounting Standards Board (Dewan Standar Akuntansi Keuangan, 2009) legalized the Financial Accounting Standards for Non-Publicly-Accountable Entities in 2009. SAK ETAP will be effective starting January 1, 2011. According to SAK ETAP (2009: 1) Financial Accounting Standards for NonPublicly-Accountable Entities (SAK ETAP) are intended for the use of entities without public accountability. Entities without public accountability are entities that 1) Have no significant public accountability and 2) Issuing general purpose financial statements for external users. Examples of external users are owners who are not directly involved in business management, creditors, and credit rating agencies. However, in its implementation, SAK ETAP faces several obstacles such as the complexity of preparing financial statements based on SAK ETAP and weak competence of MSMEs human resources in preparing financial statements (Sari \& Setyawan (2011). Lutfiaazahra (2015) and Adiya et al. (2015) also proved that SAK ETAP is not understood by the perpetrators of SMEs who tend to use simple financial statements in the form of income transactions and expenditures and to prepare the income statement and cash flow statements alone. Also, SAK ETAP is too complex and not in accordance with MSME financial reporting requirements. No supervision from the parties have an interest in MSMEs financial reports, especially from the government, related institutions and regulators also become an obstacle why SAK ETAP is difficult to be applied for MSME. The weakness of SAK ETAP is finally responded by DSAK-IAI by launching Financial Accounting Standards for Micro, Small \& Medium Entities (SAK EMKM) that effective on January 1, 2018. SAK EMKM is a fairly simple standard and does not complicate users in making financial statements. By preparing financial statements in accordance with predetermined standards, the management of the company will be able to easily determine the company policy in the future, can obtain the loan from third parties (banks and other financial institutions), etc. Most of these MSMEs are small business actors who have business prospects but do not have good access to funding sources, especially in banking. The MSME reporting framework is expected to assist the entity in transitioning from cash-based financial reporting to financial reporting on the accrual basis. So that this is in line with Article 29 paragraph 1 of Act No. 1 of 2013 on Micro Finance Institutions that require Micro Finance Institutions to conduct and maintain records and/or financial bookkeeping in accordance with the applicable Financial Accounting Standards.

(c) EY JEMA: Jurnal Ilmiah Bidang Akuntansi dan Manajemen is licensed under a Creative Commons Attribution 4.0 International License 


\subsection{Educational Background}

The research on the perception of MSME entrepreneurs regarding the implementation of financial statement information has been done by Pinasti (2007) which concluded that the implementation and use of accounting information were proven empirically in experimental research to have an effect on small entrepreneurs' perception of accounting information. The result of the discriminant analysis in the research shows that the effect of organizing and the use of accounting information is greater than the effect of individual characteristic differences on the subject perception of the research on accounting information. At this time there are still many SMEs that do the recording just by identifying the amount of money received and the amount of money spent, the number of goods purchased and sold, as well as recording the number of accounts receivable and debt. The records conducted by MSMEs still do not use the right format in making financial statements (Jati, Bala, \& Otnil, 2004). This is because MSMEs still do not provide information about financial statements for their business. The ability and expertise of the owner are determined by the level of formal education pursued, if the level of formal education undertaken by the business owner is low then the use of accounting information system will be more simple than the business owner who pursued higher education (Solovida, 2003). Likewise with research conducted by Fitriyah (2006) on the analysis of factors that affect the use of accounting information by the enterprises in Sidoarjo District which resulted that the use of high accounting information is conducted by entrepreneurs who have a high knowledge of accounting. Research conducted by Rudiantoro \& Veronica (2011) resulted that the perception of entrepreneurs variables related to the importance of financial bookkeeping and reporting for business correlated most strongly with business size, while the variables that have the significant correlation is the length of the company operates, educational background, and last education level.

$\mathrm{H}_{1}$ : The educational background of entrepreneurs has a significant effect on the MSME entrepreneurs' understanding of SAK EMKM.

\subsection{Level of Educational}

Budhijono \& Kristyowati (2005) conducted a study on accounting information systems at small businesses located in Salatiga City. The result of the study was that educational background has a positive and significant effect on the use of accounting information system in small business, which means if the business actor has a higher education then the use of accounting information system has increased. These result supported by Dewi, Yuniarta, \& Wahyuni (2017) and Wandini $\&$ Budiasih (2017) that stated the implementation of SAK ETAP depend on the MSME level of educational and socialization

$\mathrm{H}_{2}$ : The education level of entrepreneurs has a significant effect on the MSME entrepreneurs' understanding of SAK EMKM.

\subsection{Level of Information and Socialization}

Wahyuningsih \& Widayanti (2014) states that there is a positive and significant correlation between level of information and socialization and the understanding of SAK ETAP. Those result supported by Dewi, Yuniarta, \& Wahyuni (2017) that stated the implementation of SAK ETAP depend on the MSME level of educational and socialization. The higher level education and socialization of SAK ETAP the higher probability MSME in implementing SAK ETAP.

$\mathrm{H}_{3}$ : The provision of information and socialization of SAK EMKM has a significant effect on the MSME entrepreneurs' understanding of SAK EMKM. 


\section{RESEARCH METHOD}

\subsection{Research Design}

This study used a correlational approach to managers and owners of SMEs to see the factors that affect the understanding of MSME enterprises related to the implementation of Financial Accounting Standards Micro, Small and Medium Enterprises in Malang Raya. The primary data source used collection methods through questionnaires. The types of research data were subject data of managers and owners of MSME expressing opinions.. The object of analysis was the individual in example manager or owner of MSMEs. As for hypothesis testing, a model of regression equation was used as expressed in the mathematical equation as follows :

$\mathrm{Y}=\mathrm{a}+\mathrm{b}_{1} \mathrm{X}_{1}+\mathrm{b}_{2} \mathrm{X}_{2}+\mathrm{b}_{3} \mathrm{X}_{3}+\mathrm{e}$

Where

$\mathrm{Y}=$ The MSME entrepreneurs' understanding of SAK EMKM

$\mathrm{a} \quad=$ Constants

bi,b2..bn $=$ Regression Coefficient

$\mathrm{X}_{1}=$ The Entrepreneurs' last level of Education

$\mathrm{X}_{2}=$ Educational background of the entrepreneurs

$\mathrm{X}_{3}=$ Level of Information and socialization of SAK EMKM

e $=$ Standard error estimation

Table 1 Variable Definition

\begin{tabular}{|l|l|}
\hline \multicolumn{1}{|c|}{ Variable } & \multicolumn{1}{|c|}{ Definition } \\
\hline Level of Education & $\begin{array}{l}\text { The last educational strata that had been taken by the } \\
\text { respondents include graduates of SMA/SMK, S1, and S2 to } \\
\text { give an idea of how the perception of entrepreneurs on the } \\
\text { importance of financial bookkeeping and reporting for } \\
\text { business. }\end{array}$ \\
\hline Educational Background & $\begin{array}{l}\text { The field of education that has been taken by entrepreneurs } \\
\text { covering the areas of accounting, management, economics, } \\
\text { or other. }\end{array}$ \\
\hline $\begin{array}{l}\text { Level of Information and } \\
\text { Socialization of SAK EMKM }\end{array}$ & $\begin{array}{l}\text { The knowledge of MSME entrepreneurs regarding SAK } \\
\text { EMKM, the source of information related to SAK EMKM, } \\
\text { and the socialization form ever obtained by MSME } \\
\text { entrepreneurs related to SAK EMKM. The measurement of } \\
\text { this variable used a Likert scale of 4 points, that is point 1 } \\
\text { shows the respondent never get the information and point 4 } \\
\text { indicates the respondent often get the information about SAK } \\
\text { EMKM. }\end{array}$ \\
\hline $\begin{array}{l}\text { Level of SAK EMKM } \\
\text { Understanding }\end{array}$ & $\begin{array}{l}\text { The understanding of entrepreneurs is assessed through the } \\
\text { extent to which MSME entrepreneurs understand SAK } \\
\text { EMKM and the differences that entrepreneurs know between } \\
\text { PSAK and SAK EMKM. The measurement of this variable } \\
\text { used a Likert scale of 4 points, in which point 1 shows not } \\
\text { understand and point 4 shows very understand. }\end{array}$ \\
\hline
\end{tabular}




\subsection{Population and Sample}

The population of this research was the manager and owner of MSMEs in Malang Raya which covers Malang City, Malang Regency, and Batu City. The amount of sample in estimation using Maximum Likelihood (ML) is 100-200. The respondents were the manager or owner of MSME. The sampling technique was Purposive Sampling Method. The sample in this study was the companies located in the area of Malang Raya with criteria based on MSME Classification according to Law of the Republic of Indonesia Number 20 Year 2008.1) Criteria for Micro-scale enterprise is as follows: Having a net worth of at most Rp 50.000.000,00 (fifty million rupiah) excludes land and building of the business and Has annual sales of at most Rp 300,000,000.00 (three hundred million rupiah). 2). The criteria for the small-scale enterprise is as follows: a. Has a net worth of more than Rp 50,000,000.00 (fifty million rupiahs) up to a maximum of $\mathrm{Rp}$ $500,000,000.00$ (five hundred million rupiahs) excluding land and building of the business. b.has annual sales of more than Rp 300,000,000.00 (three hundred million rupiahs) up to a maximum of Rp 2,500,000,000.00 (two billion five hundred million rupiahs). 3) Medium-scale enterprise Criteria are as follows: a. Has a net worth of more than Rp 500,000,000.00 (five hundred million rupiahs) up to a maximum of $\mathrm{Rp} 10,000,000,000.00$ (ten billion rupiahs) excluding land and building of the business, has 2 or more permanent employees, 4) Owned by Indonesian citizen 5) Independent, not affiliated with medium-large business, 6) May be a legal entity, may not. 7). Produces superior product in Malang Raya (Malang City, Malang Regency, and Batu City). The Respondents Criteria are as follows: 1) Have a position as manager/owner of SMEs (Micro, small and medium enterprises), 2) Understand and use Financial Statements such as Balance Sheet, Profit, and Loss, Budget, Cash Flow etc. 3). Have access to other Banks/Financial Institutions.

\subsection{Research Framework}

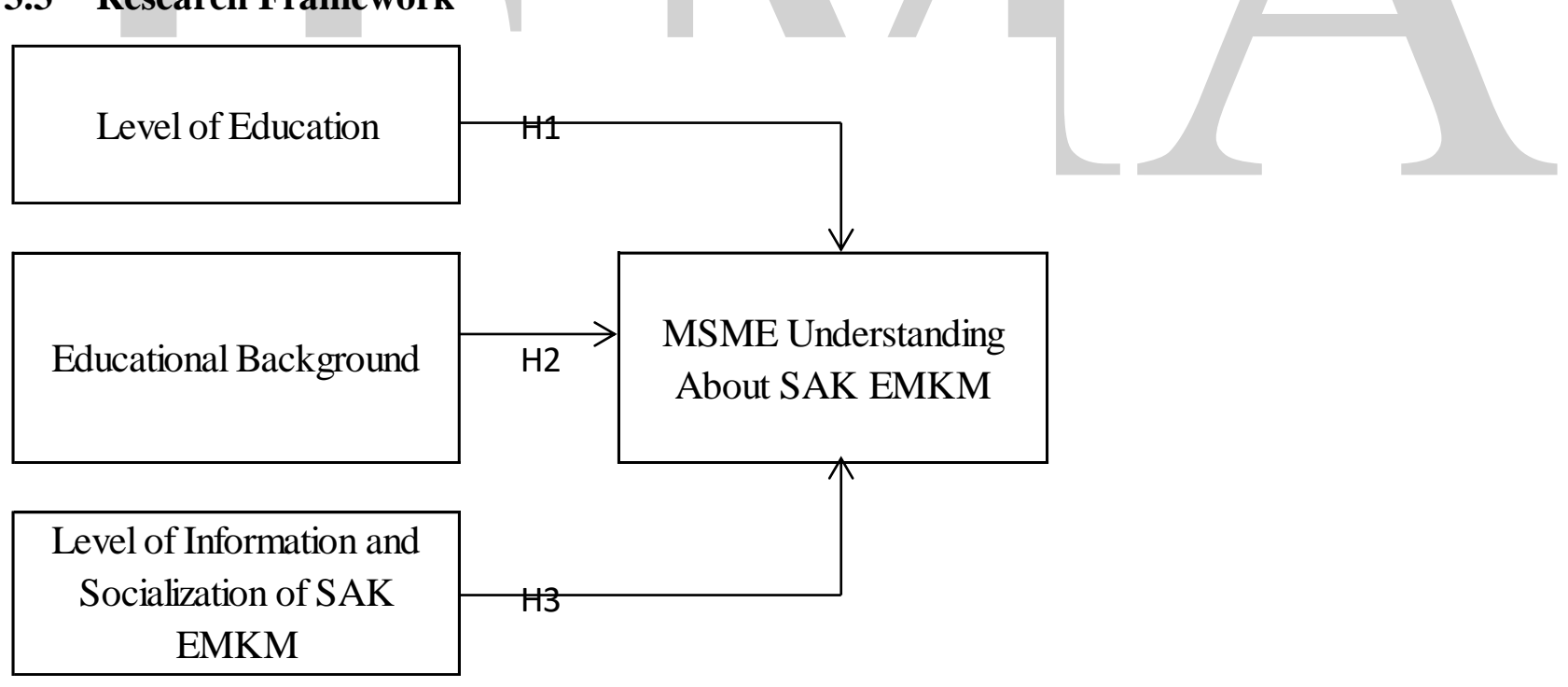

Picture 1 Research Framework

\section{RESEARCH RESULT AND ANALYSIS}

\subsection{Descriptive Analysis}

The demographics of respondent in this research are MSME owners in Malang Raya (Malang City, Malang Regency, and Batu City) with the majority of them are undergraduate (38\%), accounting degree (53\%), and choose Firma/CV/UD as the form of their business entity (53\%), 
About $39 \%$ of respondent are in the handicraft industry, with manpower capacity about 21-50 people (25\%). Interestingly, the MSME owner in this research also acted as their business manager $(62 \%)$. The majority respondent of this research also actively participated in various accounting training to escalate their accounting knowledge (54\%).

\subsection{Validity dan Reliability}

Reliability testing was using Cronbach alpha with results between 0.682 to 0.734 which has a value above 0.60 , so it is concluded that research variables are reliable. While the validity test was using analytical factor with the value of Kaiser MSA between 0.608 to 0.7213 which are above 0.50 so the research variables were concluded as valid. Reliability and validity test results in the research variables are shown in table 3 .

Table 2 Validity and Reliability Test

\begin{tabular}{|l|c|c|}
\hline \multicolumn{1}{|c|}{ Variable } & Cronbach Alpha & Kaiser MSA \\
\hline Level of Information and socialization of SAK EMKM & 0.734 & 0.643 \\
\hline $\begin{array}{l}\text { The MSME entrepreneurs understanding of SAK } \\
\text { EMKM }\end{array}$ & 0.683 & 0.721 \\
\hline
\end{tabular}

Source: Primary Data Processed, 2018

\subsection{Research Analysis}

Classic assumption tests include normality, autocorrelation, heteroscedasticity, and multicollinearity test. The test results show that :

a) In the Autocorrelation Test obtained Durbin Watson value in table 4 for $d=1.986$, while from Durbin Watson table with Durbin Watson rule table then $\mathrm{d}$ is located in range $\mathrm{dU}<\mathrm{d}<4$-dU $(1770<1.986<2.230)$ with the decision to accept $\mathrm{H} 1$ stating that there is no positive/negative correlation, or in other words that this model is free from autocorrelation problems.

b) In heteroscedasticity test with Golfeld \& Quandt method with the formula as follows: F counted $=$ Mean Square Residual klp II/Mean Square Residual klp I = 16.271/18.825 = 0.864, while $\mathrm{F}$ table $=1.882078$. So that $\mathrm{F}$ counted $<\mathrm{F}$ table, it can be concluded that this model has fulfilled the heteroscedasticity assumption.

c) The regression model is free from Multicollinearity problems when it has VIF $<10$ and a tolerance value above 0.05 . From the test results in table 1 above obtained VIF each independent variable $<10$ and tolerance values above 0.05 then in the regression there are no symptoms of Multicollinearity.

d) Regression model also passes the normality test due to the reason that Asym K-S Sig. value is more than 0.05 (0.312).

\subsection{Research Discussion}

The simultaneous test shows that there is a significant effect between independent variables to the dependent variable with the value of $F$ test $=6.643$ with significant $F=0.000$, so the level of significance is lower than $\alpha=0.05$. This shows that in general (cumulative) the variations of educational background, educational level, and level of information and socialization of SAK EMKM can predict $76.4 \%$ of the MSME entrepreneurs understanding toward SAK EMKM. It also means that $23.6 \%$ of the MSME entrepreneurs understanding toward SAK EMKM is affected by other variables. 
Table 3 Regression Analysis

\begin{tabular}{|c|c|c|c|c|c|c|}
\hline \multirow[b]{2}{*}{ Independent Variables } & \multicolumn{2}{|c|}{$\begin{array}{l}\text { Unstandardized } \\
\text { Coefficients }\end{array}$} & \multirow{2}{*}{$\mathrm{t}$} & \multirow[b]{2}{*}{ Sig } & \multicolumn{2}{|c|}{ Collinearity Statistics } \\
\hline & B & $\begin{array}{l}\text { Std. } \\
\text { Error }\end{array}$ & & & Tolerance & VIF \\
\hline (Constant) & 1.109 & 0.250 & 4.329 & 0.000 & & \\
\hline Educational background & 0.332 & 0.047 & 2.712 & 0.014 & 0.242 & 2.333 \\
\hline Educational level & 0.195 & 0.089 & 2.817 & 0.009 & 0.315 & 4.4472 \\
\hline $\begin{array}{l}\text { Level of Information and } \\
\text { socialization of SAK }\end{array}$ & & & & & & \\
\hline EMKM & 0.316 & 0.142 & 7.294 & 0.000 & 0.543 & 3.162 \\
\hline F test & 6.643 & \multirow{6}{*}{\multicolumn{5}{|c|}{$\operatorname{Sig}=0.000$}} \\
\hline Sig F & 0.000 & & & & & \\
\hline Durbin-Watson & 1.838 & & & & & \\
\hline $\mathrm{R}^{2}$ & 0.785 & & & & & \\
\hline $\operatorname{Adj} R^{2}$ & 0.764 & & & & & \\
\hline Asym K-S Sig & 0.312 & & & & & \\
\hline
\end{tabular}

Source: Primary Data Processed, 2018

Meanwhile, a partial test is conducted to find out whether the independent variables used in the research model are individually able to explain the dependent variable.

a. The Educational Background of SME Entrepreneurs on the Entrepreneurs understanding of SAK EMKM. It can be seen that the value of Educational background variable count has a t-test value of 2.712 with probability value (Sig) equal to $0.014<0.05$ then $\mathrm{H}_{1}$ is accepted, it means partially, the educational background has a significant positive effect toward the MSME entrepreneurs understanding of SAK EMKM. These result support Rudiantoro \& Veronica (2011) argument that states educational background is one of the biggest factors that help MSME in implementing their financial reporting based on SAK ETAP.

b. The Education level of SME Entrepreneurs on the Entrepreneurs' understanding of SAK EMKM. It can be seen that the value of t-values of the educational level has a t-test value of 2.817 with probability value ( $\mathrm{Sig}) 0.009<0.05$ then $\mathrm{H}_{1}$ is accepted, it means partially, the level of education has a significant positive effect toward the MSME entrepreneurs'understanding of SAK EMKM.

c. Level of Information and socialization of SAK EMKM on the Entrepreneurs' understanding of SAK EMKM. It can be seen that the $t$-value of information and socialization level of SAK EMKM has a t-test value of 7.294 with a probability value (Sig) of $0.000<0.05$ then $\mathrm{H}_{1}$ is accepted, it means that partially, the level of information and socialization SAK EMKM has a significant positive effect on the MSME entrepreneurs understanding of SAK EMKM. These result support the previous research from Dewi, Yuniarta, \& Wahyuni (2017) that stated the implementation of SAK ETAP depend on the MSME level of educational and socialization. Therefore, the higher level education and socialization of SAK ETAP the higher probability MSME in implementing SAK ETAP.

\section{RESEARCH CONCLUSION AND LIMITATION}

\subsection{Conclusion}

The purpose of this study is to provide empirical evidence on the effect of the educational background, educational level, and level of information and socialization of SAK EEMKM toward 
the level of the MSME entrepreneurs understanding of SAK EMKM. The respondents were the manager or owner of MSMEs in Malang Raya that consists of Malang City, Malang Regency, and Batu City. This research concluded that there is a significant positive correlation between educational level, educational background, and level of information and socialization of SAK EMKM to the level of MSME entrepreneurs understanding of SAK EMKM.

\subsection{Limitation}

This research has some limitations that are the data collection in this research were from perception of respondents submitted through questionnaire instrument which may affect the validity of the research results because the perceptions of respondents did not necessarily reflect the real situation, but it may be different if the questionnaire were followed by direct interviews by the researchers. The number of samples in this research also limited to MSMEs in Malang area. Thus, Tthe purpose of research in the field of behavioral accounting is to explain the phenomenon of behavior that occurred or the possibility of occurrence, but the researchers admit that it is very difficult to predict the behavior of the human/respondents with the high level of certainty.

\section{REFERENCES}

Baas, T., \& Schrooten, M. (2006). Relationship Banking and SMEs: A Theoretical Analysis. Small Business Economic, 27(2-3), 127-137. https://doi.org/10.1007/s11187-006-0018-7.

Budhijono, F., \& Kristyowati. (2005). Sistem Informasi Akuntansi pada Usaha Kecil. Akuntabilitas, 5(1), 47-60.

Cahyati, A. D., Mulyanti, K. \& Setyawasih, R. (2011). Pemahaman dan Kesiapan UKM dalam Implementasi SAK ETAP : Survey Pada Ukm Di Bekasi. Jurnal JRAK, 2(2), 19-27.

Damarjati, R. A. (2007). Exposure Draft Standar Akuntansi Keuangan Untuk Usaha Mikro, Kecil dan Menengah (UMKM) serta Analisa Perbandingannya dengan PSAK. Retrieved from lib.ui.ac.id/file?file=pdf/metadata-126426.pdf.

Dewan Standar Akuntansi Keuangan. (2009). Standar Akuntansi Keuangan Entitas Tanpa Akuntabilitas Publik. Jakarta: Ikatan Akuntan Indonesia.

Dewan Standar Akuntansi Keuangan. (2016). Standar Akuntansi Keuangan Entitas Mikro, Kecil, dan Menengah ( SAK EMKM ). Jakarta: Ikatan Akuntan Indonesia.

Dewi, N. A. P. U., Yuniarta, G. A., \& Wahyuni, M. A. (2017). Pengaruh Sosialisasi SAK ETAP, Tingkat Pendidikan Pemilik, dan Persepsi Pelaku UKM Terhadap Penggunaan SAK ETAP pada UKM di Kecamatan Buleleng. Jurnal Ilmiah Mahasiswa Akuntansi S1 UNDIKSHA, 7(1).

Fitriyah, H. (2006). Analisis Faktor-faktor yang Mempengaruhi Penggunaan Informasi Akuntansi pada Usaha Menengah Kabupaten Sidoarjo. Program Pascasarjana Universitas Airlangga. Surabaya.

Jati, H., Bala, B., \& Otnil, N. (2004). Menumbuhkan Kebiasaan Usaha Kecil Menyusun Laporan Keuangan. Jurnal Bisnis dan Usahawan, II(8), 210 - 218.

Lutfiaazahra, A. (2015). Implementasi Standar Akuntansi Keuangan Entitas Tanpa Akuntabilitas Publik (SAK ETAP) pada UMKM Pengrajin Batik di Kampoeng Batik Laweyan Surakarta. National Conference on Economics Education and Business, 215. 
JEMA: Jurnal Ilmiah Bidang Akuntansi dan Manajemen, Vol. 15 No. 2 (2018)

http://riset.unisma.ac.id/index.php/jema (e-ISSN : 2597-4071)

Pinasti, M. (2007). Pengaruh Penyelenggaraan dan Penggunaan Informasi Akuntansi terhadap Persepsi Pengusaha Kecil atas Informasi Akuntansi: Suatu Riset Eksperimen. Jurnal Riset Akuntansi Indonesia, 10(3). http://doi.org/10.33312/ijar.180.

Rudiantoro, R. S., \& Veronica, S. (2011). Kualitas Laporan Keuangan UMKM serta Prospek Implementasi SAK ETAP. Jurnal Akuntansi dan Keuangan Indonesia, 9(1). http://dx.doi.org/10.21002/jaki.2012.01.

Sari, R. N., \& Setyawan, A.B. (2011). Persepsi Pemilik Dan Pengetahuan Akuntansi Pelaku Usaha Kecil Dan Menengah Atas Penggunaan Informasi Akuntansi, Retrieved from http://arisbudi.staff.gunadarma.ac.id/Publications/files/1836/Persepsi+dan+Pengetahuan+Aku ntansi+UKM_Ria.pdf .

Solovida, G. T. (2003). Analisis Faktor-Faktor yang Mempengaruhi Penyiapan dan Penggunaan Informasi Akuntansi pada Perusahaan Kecil dan Menengah di Jawa Tengah (Doctoral dissertation, Program Pascasarjana Universitas Diponegoro).

Tambunan, T. (2012). Usaha Mikro Kecil dan Menengah di Indonesia, Isu-Isu Penting. Jakarta: LP3ES.

Undang-Undang Republik Indonesia Nomor 20 Tahun 2008 tentang Usaha Mikro, Kecil, dan Menengah.

Wahdini, S. (2006). Persepsi Akuntan Terhadap Overload Standar Akuntansi Keuangan (SAK) Bagi Usaha Kecil dan Menengah. Simposium Nasional Akuntansi IX, 24-25.

Wahyuningsih, E. M, \& Widayanti, R. (2014). Pengaruh Sosialisasi, Tingkat Pemahaman, Motivasi, Kepribadian Terhadap Penerapan SAK ETAP di Kampung Batik Laweyan Solo. Jurnal Paradigma, 12(2), 179-187.

Wandini, N. W. Z. P., \& Budiasih, I. G. A. N. (2017). Pengaruh Tingkat Pendidikan, Pengalaman, Pemanfaatan Teknologi Informasi Akuntansi Pada Penerapan SAK ETAP. E-Jurnal Akuntansi Universitas Udayana, 21, 2108-2133. https://doi.org/10.24843/EJA.2017.v21.i03.p15.

*) Nur Diana, Department of Accounting, University of Islam Malang, Malang, Indonesia (Email : nurdiana2016@ unisma.ac.id) 